\title{
The Use of Natural Dyes from Beetroot Skin Extract (Beta Vulgaris) as Teaching Material on Cell Division for Senior High School Students
}

\author{
Adilla Nur Azizah ${ }^{1}$, Putri Agustina ${ }^{2}$, Suparti $^{3}$, Alanindra Saputra ${ }^{4}$, Yasir Sidiq ${ }^{5}$ \\ ${ }^{1,2,3}$ Faculty of Teacher Training Education, Universitas Muhammadiyah Surakarta, Indonesia \\ ${ }^{4}$ Faculty of Teacher Training Education, Universitas Sebelas Maret, Indonesia \\ ${ }^{5}$ Biological Science, Kanazawa University, Japan
}

DOI: 10.23917/ijolae.v2i1.9051

Received: October $16^{\text {th }}, 2019$. Revised: October $26^{\text {th }}, 2019$. Accepted: October $27^{\text {th }}, 2019$. Available Online: October $28^{\text {th }}, 2019$. Published Regulary: January $1^{\text {st }}, 2020$.

\begin{abstract}
One of the Basic Competencies (KD) in Biology for Indonesian Senior High School is KD 4.12 which reads "Presents observations of the process of mitosis in the onion root and determines the phases it finds". Based on the basic competency test, students are required to have skills in making and observing mitotic preparations of plant tissue with at least using onion. Observation of mitotic division in plant tissues requires skill in making preparations. Making preparations in observing cells and tissues of plants or animals needs staining. Dyes often used in lab work are synthetic dyes. One of the synthetic dyes commonly used is safranin. However, safranin is quite expensive. This limitation requires teachers to look for alternatives to synthetic dyes that are easily found at a more affordable price, namely with natural dyes. One of the plants that has the potential to overcome this issue is beetroot (Beta vulgaris). The purpose of this study was to determine the quality of plant tissue preparations (Allium cepa) stained with beetroot skin (Beta vulgaris) as a natural coloring agent. The research method used was an experimental method with a Completely Randomized Design consisting of two factors, namely the staining time (1 hour, 2 hours, and 3 hours) and the type of solvent (aquades and citric acid 10\%). The results of the study were analyzed with qualitative descriptive methods which included contrast and clarity of the preparations. Based on the results of the study, the quality of Allium cepa root preparations using beetroot (Beta vulgaris) skin extract with variations in the type of solvent and duration of staining showed good results on the staining time of 1 hour and 2 hours. The staining time of the preparations can affect the contrast and clarity of the preparations.
\end{abstract}

Keywords: beetroot skin, mitosis, plant cell, research based learning.

Corresponding Author:

Putri Agustina, Faculty of Teacher Training Education, Universitas Muhammadiyah Surakarta, Indonesia. e-mail:pal82@ums.ac.id

\section{Introduction}

One of the Basic Competencies (KD) of Biology in Indonesian Senior High School (SMA) class $\mathrm{XII}$ is $\mathrm{KD} 4.12$ which reads "Presents observations of the process of mitosis in the onion root and determines the phases it finds". This basic competency demands students' skills to be able to observe mitotic division in plant tissue, which in this case is a minimum of shallot roots. Observation of mitotic division in plant tissues requires skill in making preparations. Making preparations in observing cells and tissues of plants or animals is in dire need of staining. Wahyuni (2008) states that coloring aims to sharpen or clarify various tissue elements, especially cells. Without coloring, the cells and tissues of plants or animals will be transparent making it difficult to observe.

Coloring according to Saidi (2010) is the process of giving color to the tissue that has been cut so that the tissue elements become 
contrasted and can be identified using a microscope. The process of the emergence of color in the colored tissue is bound by the formation of molecular bonds between the dye with certain tissues. Dyes bound to the tissue will absorb light with a certain wavelength so that the tissue will appear colored.

Observation of cells and tissues under a microscope can be clarified by the presence of coloring. However, each part of the cell has special characteristics so that the affinity of these parts for dyes also varies. The ability to dye tissue by dyes also depends on the properties of the dye. So it is very necessary to recognize the properties of dyes (Suntoro, 1983).

The problem that is often faced in the observation of plant tissue preparations is the unavailability of preparations and practicum of plant tissue is considered complicated. This problem occurs because the price of preparations is relatively expensive and plant specimens used as preparations are not recognized by students. As for the manufacture of preserved preparations, equipment and materials that are relatively difficult to obtain are needed such as microtomes, paraffin, and coloring agents and quite a long time. Furthermore, the use of preserved preparations cannot hone students' skills in making preparations so that the scientific process to be achieved in practicum is not fulfilled (Apriani, 2016). This problem is then solved by making a wet preparation.

Making wet preparations to observe the division of mitosis in plant tissue requires coloring. Dyes that are often used in lab work are synthetic dyes. One of the synthetic dyes commonly used is safranin. Safranin is one of the synthetic dyes with red coloring. The price of safranin as a synthetic coloring agent is quite expensive at Rp. 85,000 up to Rp. 100,000 per $100 \mathrm{ml}$ for dyes with a concentration of $0.25 \%$ (Wahyuni, 2010).
This limitation requires teachers to look for alternatives to synthetic dyes that are easily found at a more affordable price, namely with natural dyes.

Natural dyes according to Kwartiningsih et al (2009) can be used as an alternative because besides being cheap, the use of natural materials is safer for students to use. The color that comes from natural dyes comes from natural coloring pigments themselves such as chlorophyll, carotenoids, tannins, and anthocyanins. Each plant can be used as a source of natural color because it contains natural pigments. This potential is determined by the intensity of the color produced and is very dependent on the type of coloring matter that exists. Coloring matter is a substance that determines the color direction of natural dyes and is an organic compound contained in the source of natural dyes (Wismaji, 2008).

One of the plants that has the potential to be developed as a natural coloring is beetroot (Beta vulgaris). Beets are found in Europe, Asia and America. Red beet (Beta vulgaris L.) or often also called as beetroot is a rootshaped plant that resembles tubers and comes from the family Amaranthaceae. In the content of red beets, potential vitamins are folic acid and vitamin $\mathrm{C}$, while viewed from the mineral content of manganese, potassium, magnesium, iron, copper, and phosphorus. The content of vitamin $\mathrm{C}$ is high enough to make red beets can be used as a source of antioxidants. The content of pigment in red beets, namely betacyanin is believed to be very useful for preventing cancer, especially colon cancer (large intestine) (Santiago and Yahia, 2008).

In Halim's (2011) research, beetroot is known to reduce a person's blood pressure by drinking $200 \mathrm{ml} /$ day. The average systolic blood pressure decreased by $11.48 \mathrm{mmHg}$ while the diastolic pressure was $5.75 \mathrm{mmHg}$. Beets also contain vitamin $\mathrm{C}$ which is high enough so that it can be used as an 
antioxidant that can prevent cancer. In addition to antioxidants, beets also have a major component, the betacyanin pigment which gives a purplish red color (Wibawanto, 2014).

Beetroot contains betacyanin pigment of $1000 \mathrm{mg} / 100 \mathrm{~g}$ dry weight or $120 \mathrm{mg} / 100$ $\mathrm{g}$ wet weight. There are two groups of betalain pigments in the beetroot, namely red betetination violet pigments and yellow betaxanthine pigments. Comparison of concentrations between betacyanin pigments and betaxanthine pigments is usually in the range of $1: 3$. This ratio varies depending on beet varieties. The comparison that causes variations in the red color of beets and beet extracts (Andarwulan, 2012).

Based on the background description above, the purpose of this research is to determine the quality of plant tissue preparations (Allium cepa) stained with beetroot skin (Beta vulgaris) as a natural coloring agent. This research is expected to be a solution to the high cost of synthetic dyes as coloring preparations for plant tissue mitosis. The results of this study can be used as a source of learning for senior high school students, namely in cell division material.

\section{Method}

This research is one part of the development research $(\mathrm{RnD})$ carried out in the Biology Laboratory of the Teacher Training and Education Faculty of Muhammadiyah University, Surakarta. The study was conducted from February to August 2018. The stages carried out in this study were the initial stages of developing cell division material teaching materials, namely the preliminary research stage.

Tools used in making beetroot peel extract: $500 \mathrm{ml}$ beaker glass (Pyrex), knives, stirring rods, digital scales (AND), measuring cups (Pyrex) $100 \mathrm{ml}$, filter paper and label paper. Tools used in making Allium cepa root preparations: cutter/razor blade, flacon bottle, aluminum foil, isopropyl alcohol, tricycle, gauze, $500 \mathrm{ml}$ beaker glass (Pyrex), thermometer, brush, petri dish. Tool used in observing mitosis Allium cepa: Olympus CX 21 microscope, object glass, deck glass, brush.

Ingredients used in making beetroot peel extract: beet peel, citric acid 10\%, aquades. Ingredients used in making Allium cepa root preparations: Allium cepa root, $\mathrm{HCl} 1 \mathrm{~N}$, water, beetroot bark extract, safranin. Ingredients used in observing mitosis Allium cepa: alcohol, tissue.

The experimental design in this study was a Completely Randomized Design (CRD) consisting of two factors, namely the staining time (L) and the type of solvent (P). The coloring factor consists of 3 combinations: 1 hour (L1), 2 hours (L2), and 3 hours (L3). While the solvent type factor consists of two combinations, namely aquades (P1) and citric acid 10\% (P2). The combination of treatments was modified from the Izzati's study (2017).

The research procedure consisted of several stages, namely:

\section{a. Making Beetroot Skin Extract}

Making beetroot peel extract is done by chopping beetroot peels and weighing as much as 2 grams. The chopped is then put into 2 beaker glass each 1 gram chopped. Then in the first beaker glass added $10 \mathrm{ml}$ of distilled water while the second was added $10 \mathrm{ml}$ of $10 \%$ citric acid with the ratio of ingredients: solvent $(1: 10)$. The mixture of ingredients and solvents is then stirred until homogeneous to get maximum results. After that, the extraction results are separated by filtering the beetroot peel using a filter paper.

\section{b. Making preparations}

Take the onion tubers that have roots, then cut the root tip of Allium cepa $\pm 2 \mathrm{~mm}$ using a razor blade/cutter transversely as much as 5 roots at 09.00-10.00 am. Then put the root pieces into a flacon bottle and soak with $1 \mathrm{~N} \mathrm{HCl}$ as much as 5 drops for \pm 5 
minutes. After that, close the flacon bottle with aluminum foil, then boil it in boiling water at $60^{\circ} \mathrm{C}$ for 1 minute. Then take a flacon bottle containing the preparation, then wash it with distilled water as much as 3 times and pour the roots of Allium cepa into a petri dish so that it is easy to take.

c. Observation

Giving staining with natural color beetroot extract bark according to the variation of the solvent and the staining time that has been done as a combination treatment. Then observed under a microscope. The results obtained were documented and analyzed then compared between solvents using distilled water and $10 \%$ citric acid and the staining time of the preparations (1, 2, 3 hours).

Data analysis in this research was descriptive qualitative which included color contrast and clarity of preparations from beet root skin extracts which were used as natural dyes for plant tissue preparations (Allium сера). The contrast and clarity criteria of preparations according to Wahyuni (2015) are presented in Table 1 and Table 2.

Table 1. Clarity Preparation Criteria

\begin{tabular}{cll}
\hline No. & Criteria & Indicators \\
\hline 1 & Very Clear & If mitotic division can be distinguished very clearly \\
2 & Clear & If mitotic division can be clearly distinguished \\
3 & Not Clear & If mitotic division cannot be clearly distinguished \\
\hline
\end{tabular}

Table 2. Observation of fast Allium cepa cell division for color contrast

\begin{tabular}{cll}
\hline No. & \multicolumn{1}{c}{ Criteria } & \multicolumn{1}{c}{ Indicators } \\
\hline 1 & Very contrast & When the dye is very tightly bound to the chromosomes \\
2 & Contrast & If the dye is only firmly attached to the chromosome \\
3 & Not contrast & If the coloring coloring all tissues \\
\hline
\end{tabular}

The results of this study are then packaged in the form of teaching materials that will be tested for eligibility in future studies.

\section{Result and Discussion}

The study was carried out using 24 samples of Allium cepa root mitosis preparations which were stained using beetroot skin (Beta vulgaris) as a natural coloring agent with variations of aqueous solvent and citric acid variations of $10 \%$ and duration of staining for 1,2 , and 3 hours. Complete observations are presented in Table 3.

Table 3. Results of Observation of the Quality of Allium cepa Root Mitosis Preparations Colored with Beet Skin Extract (Beta Vulgaris)

\begin{tabular}{ccc}
\hline \multirow{2}{*}{ Treatment } & \multicolumn{3}{c}{ Parameter } \\
\cline { 2 - 3 } & Preparation Clarity & Preparation Color Contrast \\
\hline $\mathrm{L}_{1} \mathrm{P}_{1}$ & Clear & Contrast \\
$\mathrm{L}_{1} \mathrm{P}_{2}$ & Clear & Contrast \\
$\mathrm{L}_{2} \mathrm{P}_{1}$ & Clear & Contrast \\
$\mathrm{L}_{2} \mathrm{P}_{2}$ & Clear & Contrast \\
$\mathrm{L}_{3} \mathrm{P}_{1}$ & Not clear & Not contrast \\
$\mathrm{L}_{3} \mathrm{P}_{2}$ & Not clear & Not contrast \\
\hline
\end{tabular}

Based on Table 3 the results of preparations of Allium cepa root stained observations of the quality of the mitosis using beetroot skin (Beta vulgaris) with 2 
treatment factors namely duration of staining and type of solvent, the results showed that the staining time of 1 hour and 2 hours of preparation was clearly visible and contrasted using either distilled water or citric acid solvents. However, at the 3 hour staining time the preparation was unclear and did not contrast. Based on observations, it can be concluded that the longer the staining, the preparations will be increasingly unclear and not contrasting. This is because the cell wall has a neutral $\mathrm{pH}$ and natural dyes have an acidic pH so the color is more bound to the cell wall (Izzati, 2017).

In observing the mitosis of Allium cepa root that need attention is the color contrast and clarity of the preparation. In order to make the preparations clearly visible, staining is carried out on the preparations, a dye which is usually used is safranin. However, the price of safranin which is quite expensive requires teachers to look for alternative dyes that are easily found at prices that are more affordable but have the same function. Therefore, this research is expected to help teachers reduce costs in making preparations by finding alternative natural dyes. The use of natural dyes is also safer to use because the rest of its use is easily broken down by bacteria than synthetic dyes (Mahayana, 2012). In this study using a dye from the skin of beetroot (Beta vulgaris).

Beetroot dye is produced by maceration method with 2 variations of the type of solvent treatment, namely aquades and citric acid. Aquades is a polar organic solution and is a neutral solution. While citric acid (C6H8O7) is a polar organic solvent (Blue), 2010). The use of 2 different types of solvents aims to compare the ability of the two types of solvents to produce betacyanin pigments. While the staining time of the preparations aims to determine the effect of Allium cepa root immersion on beet root peel extract on the color contrast and clarity of the preparations.

Based on observations, the type of aquades solvent with 1 hour (L1P1), 2 hour (L2P1) and 3 hour (L3P1) coloration has different results. At 1 hour (L1P1) and 2 hour (L2P1) staining the clarity of the preparations is clearly visible because mitotic division can be clearly distinguished. Color contrast is also contrasted because the dye is only strongly bound to the chromosomes. Whereas at 3 hours (L3P1) staining the clarity of the preparations was not clear because the division of mitosis could not be clearly distinguished. Likewise with the contrast of the preparations, the 3 hour (L3P1) staining time does not contrast because the coloring coloring all tissues. This is consistent with Anisa's research (2017) which states that the quality of preparations with a type of distilled water and $10 \%$ citric acid at 1 hour and 2 hour staining time showed good results. According to Eder (1996) betacyanin has a high solubility in water so extraction is usually done with a water solvent or using a mixture of water: ethanol (1: 1).

Types of citric acid solvents with 1 hour (L1P2), 2 hour (L2P2), and 3 hour (L3P2) staining results for clarity of the preparations and contrast of different colors. At 1 hour (L1P2) and 2 hour (L2P2) staining, preparations are clearly visible because mitotic division can be clearly distinguished. Color contrast is also seen as contrast because the dye is only tightly bound to the chromosomes. Whereas for 3 hours (L3P2) staining time, the preparation was unclear and did not contrast. This is due to the fact that mitotic division cannot be clearly distinguished and dyes dye all tissues. This is also in accordance with research by Izzati (2017) which states that coloring with citric acid is better than aquades. The addition of citric acid has the function of denaturing cells so that with higher concentrations of 
citric acid, many cell membranes are degraded so that the pigment component easily exits the membrane to produce more yield (Surianti, 2012).

In safranin control, the clarity of preparations is very clear because the division of mitosis can be distinguished very clearly. Similarly, the contrast of colors looks very contrasting because the dye is very tightly bound to the chromosomes. The process of coloring the preparations is influenced by the $\mathrm{pH}$ contained in the cell nucleus. Allium cepa root cell nuclei have acidic $\mathrm{pH}$ while safranin dyes have a basic $\mathrm{pH}$. Acidic dyes color the base cells and vice versa (Nurwanti, 2013).

\section{Conclusion}

Based on the results of data analysis and observations, it can be concluded that the quality of Allium cepa root preparations using beetroot extract (Beta vulgaris) with various types of solvent and staining time showed good results on staining time of 1 hour and 2 hours. The results of the study can be used as teaching materials in Biology class as modules or worksheets for students. Steps for developing these learning materials done in the next study.

\section{References}

Anisa, C. (2017). Kualitas Preparat Mitosis Allium cepa Menggunakan Pewarna Ekstrak Kulit Ubi Jalar Ungu Dengan Variasi Pelarut Dan Lama Pewarnaan. Skripsi.

Eder, R. (1996). Handbook of Food Analysis, Vol. I. New York: Marcel Dekker Inc.

Halim, S. (2011). Pengaruh Jus Beet (Beta vulgaris L.) terhadap Tekanan Darah. Skripsi.

Harsh Chawla, M. P. (2016). Beetroot: A Health Promoting Functional Food. Article.

Hastuti, A. (2013). Penerapan Pembelajaran Berbasis Praktikum untuk Meningkatkan Motivasi dan Hasil
Belajar Biologi Materi Pokok Sistem Reproduksi Manusia. Skripsi.

Hastuti, A. (2013). Pengaruh Pembelajaran Berbasis Praktikum Untuk Meningkatkan Motivasi dan Hasil Belajar Biologi Materi Pokok Siste Reproduksi Manusia. Yogyakarta: UIN Sunan Kaijaga.

Izzati, M. (2017). Kualitas Preparat Mitosis Allium cepa Menggunakan Pewarna Ekstrak Kulit Buah Naga Merah Dengan Pelarut Akuades dan Asam Sitrat 10\%. Skripsi.

Kumar, Y. (2011). Beetroot: A superfood. International Journal of Engineering Studies and technical Approach.

Lazuardi, R.N.M. (2010). Mempelajari Ekstraksi Pigmen Antosianin Dari Kulit Manggis (Garcinia mangostana L.) dengan Berbagai Jenis Pelarut. Skripsi.

M. Nurwanti, B. J. (2013). Pemanfaatan Filtrat Daun Muda Jati sebagai Bahan Pewarna Alternatif dalam Pembuatan Preparat Jaringan Tumbuhan. Jurnal BioEduVol. 2 No. 1.

Mahayana, A. (2012). Pengaruh Pelarut dan Waktu Ekstraksi Pada Isolasi Zat Warna Dari Daun Jati. Skripsi.

Nanda Rudy Wibawanto, V. K. (2014).

Produksi Serbuk Pewarna Alami Bit Merah (Beta vulgaris L.) dengan Metode Oven Drying. Prosiding SNST.

Neil A. Campbell, J. B. (1999). Biology. San Fransisco: Pearson Benjamin Cummings.

Nemzer Boris, Z. P. (2011). Betalainic And Nutritional Profiles Of PigmentEnriched Red Bit Root (Beta vulgaris

L.) Dried Extracts. Food Chemistry 127.

Retno, M. (2010). Identifikasi Pigmen Betasianin pada Beberapa Jenis Inflorescence Celosia. Skripsi.

Saroh, S. (2011). Pemanfaatan Ekstrak Kulit Buah Naga (Hylocereus undatus) dan Ekstrak Ubi Jalar Varietas Ungu (Ipomoea batatas) Sebagai PewarnaAlami Untuk Pengamatan Stomata. Skripsi. 
Sumiatun. (2013). Analisis Mutu Pembelajaran Praktikum Kebidanan Sebagai Upaya Peningkatan Pencapaian Kompetensi Program Studi Diploma III Kebidanan STIKES Maharani Malang. Jurnal Kebijakan dan Pengembangan Pendidikan Volume 1, Nomor 1.

Sutrian, Y. (2011). Pengantar Anatomi Tumbuh-Tumbuhan: Tentang Sel dan Jaringan. Jakarta: Rineka Cipta.

Tjitrosoepomo, G. (2010). Taksonomi Tumbuhan. Yogyakarta: UGM Press.

Wahyuni, S. (2015). Identifikasi Preparat Gosok Tulang (Bone) Berdasarkan Teknik Pewarnaan. Prosiding Seminar Nasional Pendidikan Biologi 2015, yang diselenggarakan oleh Prodi Pendidikan Biologi FKIP Universitas.
Wahyuni, S. I. (2010). Pengamatan Inti Sel Ujung Akar Allium cepa Menggunakan Pewarna Alternatif Daun Jati Muda (Tectona grandis) Dan Daun Jambu Monyet (Annacardium occidentale L.). Skripsi.

Wibowo, S. (2008). Budidaya Bawang Putih, Bawang Merah dan Bawang Bombay. Jakarta: Penebar Swadaya.

Yahia, E. S. (2008). Identification and Quantification of Betalains From the Fruit of 10 Mexican Prickly Pear Cultivars by High-Performance Liquid Chromatography. Journal Agric. Food Chem.

Zain, S. B. (2010). Strategi Belajar Mengajar. Jakarta: Rineka Cipta. 